\title{
The Perspectives Regarding Euthanasia of the Students at the Faculties of Veterinary Medicine: Kafkas and Adnan Menderes University
}

\author{
Kafkas ve Adnan Menderes Üniversitesi Veteriner Fakültesi Öğrencilerinin Ötenaziye Bakıs Açıları
}

\section{(iD) Aysun KOÇ1, (D) Pınar DEMİR ${ }^{2 *}$}

${ }^{1}$ Aydın Adnan Menderes Üniversitesi, Veteriner Fakültesi, Klinik Öncesi Bilimleri Bölümü, Veteriner Hekimliği Tarihi ve Deontoloji Anabilim Dalı, Aydın, Türkiye

${ }^{2}$ Kafkas Üniversitesi, Ceyhan Veteriner Fakültesi, Hayvancılık Ekonomisi ve İşletmeciliği Anabilim Dalı, Kars, Türkiye

Abstract: This study was carried out in order to find out the opinions and general knowledge levels of the students in the Faculty of Veterinary Medicine regarding euthanasia. The material of the research was the data obtained from the survey that was carried out with face-to-face interviews with 638 students, consisting of 320 students from Kafkas University and 318 students from Adnan Menderes University. In the study, it was determined that the average age of the students, who participated in the study, was 23.09 1.45 ; and $70.5 \%$ of them had gained information about euthanasia during their educations at the school. When the views of the faculty of veterinary medicine students on the euthanasia were analyzed, it was determined that $71.2 \%$ of participants deemed appropriate that euthanasia can be applied to the animals in the required situations. It was found that $83.1 \%$ of the participants had the idea that euthanasia demands of the animal owners should be considered by the veterinarian, and $55.5 \%$ of the students thought that religious beliefs should not be regarded as an important reference in the discussions about animal euthanasia. It was determined that there are differences in the views of the veterinarian candidates studying in faculty of veterinary medicine depending on demographic structure, gender, culture and lifestyle.

Keywords: Death, euthanasia, opinion, veterinary faculty, student

Öz: Bu çalışma, veteriner fakültesi öğrencilerinin ötenazi hakkındaki genel bilgi ve görüşlerini belirlemek amacıyla yapılmıştır. Araştırmanın materyalini Kafkas Üniversitesi'nden 320, Adnan Menderes Üniversitesi'nden 318 olmak üzere 638 öğrenci ile yüz yüze yapılan anketten elde edilen veriler oluşturmuştur. Yapılan çalışmada, araştırma kapsamına alınan öğrencilerin yaş ortalamasının 23.09£1.45 olduğu ve \%70.5’inin ötenazi hakkındaki bilgiyi okul eğitimi sırasında aldığ1 belirlenmiştir. Veteriner fakültesi öğrencilerinin ötenaziye ilişkin görüşleri incelendiğinde, katılımcıların \%71.2'sine göre gerekli durumlarda hayvanlara ötenazi uygulaması yapılabileceğini uygun buldukları belirlenmiştir. Katılımcıların \%83,1'inin hayvan sahiplerinin hasta hayvanları için ötenazi isteğinin veteriner hekim tarafından dikkate alınması gerektiğini düşündükleri ve \%55.5’inin dini inançların hayvanlara ötenazi tartışmalarında önemli bir referans olarak kabul edilmemesi gerektiğini düşündükleri tespit edilmiştir. Veteriner fakültesinde okuyan veteriner hekim adaylarının ötenaziye yaklaşımları konusunda demografik yapı, cinsiyet, kültürel ve yaşam tarzlarına göre farklılıkların önemli olduğu belirlenmiştir.

\begin{tabular}{ll}
\hline Anahtar Kelimeler: Ölüm, ötenazi, görüş, veteriner fakültesi, öğrenci \\
\hline *Corresponding author : Pınar DEMİR & e-mail : pinardemir80@hotmail.com \\
Geliş tarihi / Received : 27.06.2018 & Kabul tarihi / Accepted: 16.10.2018 \\
\hline
\end{tabular}

\section{Introduction}

Starting from the ancient era; animals, which have been grown by human beings in the context of human-centered animal-human relationship, have been forced to reproduce and exist in the direction of the desires of the human being
(Morris 1990; Morris 1991). However, as the result of the modern lifestyle, the emotions, ideas and behaviors that are the subjects of medical ethics have also become valid for the animals, and the Universal Declaration of Animal Rights was signed in 1978 (Yaşar, 1997). Additionally, today, 
the issues regarding animal health and welfare have come to the forefront.

Euthanasia is the medical abolition of the life of a patient, who has to live with a disease that cannot be treated in any way, and which causes humane sentiment in a person (Nehir et al. 2006; Aypar, 1997). The act of killing, which comes up in the circumstances such as upcoming death, intolerable suffering, loss of life quality at an advanced level, and life becoming only sustainable by medical support and only applied with the purpose of helping the one who is killed; constitutes a different option for the discussions of the characteristic of death, within the context of addressing it in conceptual-institutional level (Can et al. 2006).

One of the most controversial issues in medicine and veterinary medicine is the concept of euthanasia. "Euthanasia" meant "comfortable and easy death" in the ancient Greek, as the combination of the words "eu", which means comfortable, and "thanatos" meaning death (Soysal, 1999). On the basis of countries, there are differences in the approaches accepted regarding the legal framework, registration, struggle against street animals, and euthanasia. Especially in Belgium, Denmark, Germany, Netherlands, Sweden, Norway and Switzerland, dogs are placed in animal shelters within the context of struggle against the street animals, and the dogs, which could not be placed in those shelters, may be subject to euthanasia. On the other hand, in Greece, Czech Republic and Italy, euthanasia is prohibited by law. In France and England, lost or abandoned street animals are held in the shelters for only a temporary time. For the animals, which are not owned or re-owned in this temporary timeframe, euthanasia is applied under the supervision of veterinarians (Yaşar, 1997; Anonim, 2011).

In Turkey, according to the $9^{\text {th }}$ Article titled "Animal Welfare" of Law No.5996, which is named as "Law on Veterinary Services, Plant Health, Nutrition and Feed"; "Applying euthanasia on the animals is prohibited". However, the legal responsibilities of the veterinarians are indicated with the articles,

a) "In cases of the illnesses that cause pain and suffering or there's no chance of healing,"

b) "For the purposes of prevention or eradication of an acutely infectious animal disease or in situations, which pose danger for the human health,"

c) "In the situations of behaviors that are dangerous for the existence and the health of humans and animals and in cases that the negative behaviors cannot be controlled, euthanasia is applied by the veterinarians".

Euthanasia, which is important in medical, ethical and legal terms throughout the world, is a concept that is still discussed in numerous different studies. Although there are studies evaluating the points of views of the health personnel on euthanasia, particularly in the field of medical deontology (Ay, 2013; Tepehan et al 2011), but no studies were found on the views of the veterinary students in Turkey. Yet, it is important to identify and evaluate the views of the veterinary students, who will become veterinarians in the following years, about euthanasia. This research was conducted to determine the views of the students, who are studying at Faculty of Veterinary Medicine at Adnan Menderes University and Kafkas University, located in the western and eastern regions of Turkey, on euthanasia.

\section{Material and Method}

This study was performed with the students of Faculty of Veterinary Medicine of Adnan Menderes University (ADUVF), located in the western part of Turkey, and Kafkas University (KUVF), located in the eastern part of Turkey, in the academic year of 2016-2017. A total of 638

\footnotetext{
${ }^{1}$ Official Gazette dated June 11, 2010 and numbered 27610
} 
students, consisting of 320 students from Kafkas University and 318 students from Adnan Menderes University, voluntarily participated in the survey study and the survey that was carried out with face-to-face interviews with students. Obtained sample was $48.5 \%$ of the KUVF's total population, and $54.7 \%$ of the ADUVF's total population.

A three-part questionnaire was applied to the students. Demographical characteristics of the participants in the first section, level of knowledge about the euthanasia in the second section, and the opinions about the topic in the third section were tried to be determined.

In analyzing the collected data as the result of the survey study, SPSS for Windows 15 program was utilized; and the obtained data were presented in tables as frequency distributions and percentages. Additionally, the Chi-square test was applied in order to determine whether there was a statistically significant difference between the responses of the students. During analyzes, the level of significance was accepted as $\mathrm{P}<0.05$ (Düzgüneş et al 1983).

\section{Results}

It was determined that, $14.4 \%$ of the students who participated in the survey were in the $1^{\text {st }}$ year,
$21.3 \%$ were in the $2^{\text {nd }}$ year, $21.2 \%$ were in the $3^{\text {rd }}$ year, $24.6 \%$ were in the $4^{\text {th }}$ year and $18.5 \%$ were in the $5^{\text {th }}$ year of their school. In the survey study, $94.1 \%$ of the students stated that they knew the dictionary meaning of euthanasia, $55.6 \%$ of the students, who thought that they had sufficient knowledge about euthanasia, and $36.4 \%$ of the students had partial knowledge. While $70.5 \%$ of the participants stated that they gained information about euthanasia during their education at the faculty of veterinary medicine, $12.5 \%$ stated that they learned from media and similar publications, and $3.7 \%$ expressed that they learned about euthanasia with informative presentations such as conferences and seminars, and the rate of the participants that learned about euthanasia in environments consisting of family and friends was determined as $13.3 \% .54 .9 \%$ of students stated that euthanasia may be practiced in humans in compulsory situations (in cases of illness where there is pain-suffering and/or no chance of recovery), provided that the patient's request and approval are obtained; and the percentage of the students, who stated that euthanasia should be applied on animals in the required situations was $71.2 \%$. The general opinions of the students on applying euthanasia on animals are given in Table 1.

Table 1. Views on the application of euthanasia

\begin{tabular}{lcc}
\hline Views & Frekans (n) & Percent (\%) \\
\hline It is a medical practice, it is applicable & 454 & 71,2 \\
It is not applicable, because; & 184 & 28,8 \\
$\quad$ - The rights of animals to exist & 40 & 6,3 \\
- Intentional animal killing & 35 & 7,8 \\
- The veterinarian should keep them alive & 32 & 8,9 \\
- Religious reasons & 26 & 4,1 \\
$\quad$ - Conscientious discomfort & 20 & 6,3 \\
$\quad$ - No idea & 31 & 4,8 \\
\hline Total & 638 & 100,0 \\
\hline
\end{tabular}


When Table 1 is examined, it is seen that $71.2 \%$, which is an important proportion, of the students, who participated in the survey study think that euthanasia is a medical practice. $4.8 \%$ of participants expressed that they had no idea about this issue, and the proportion of those who were against euthanasia for various reasons in all conditions was determined as $24 \%$.

The average age of the students who participated in the survey study was $23.09 \pm 1.45$; and it was determined that $34.3 \%$ of them were female, $65.7 \%$ were male; and the average monthly income of the household was $\$ 848$. In the study, $51.4 \%$ of the students were residing in cities, $28.5 \%$ were in the provinces, and $20.1 \%$ were in the villages. According to this information, the relationship between the students' perspectives regarding the practice of euthanasia on humans and animals is presented in Table 2.

Table 2. Students' perspectives regarding the practice of euthanasia

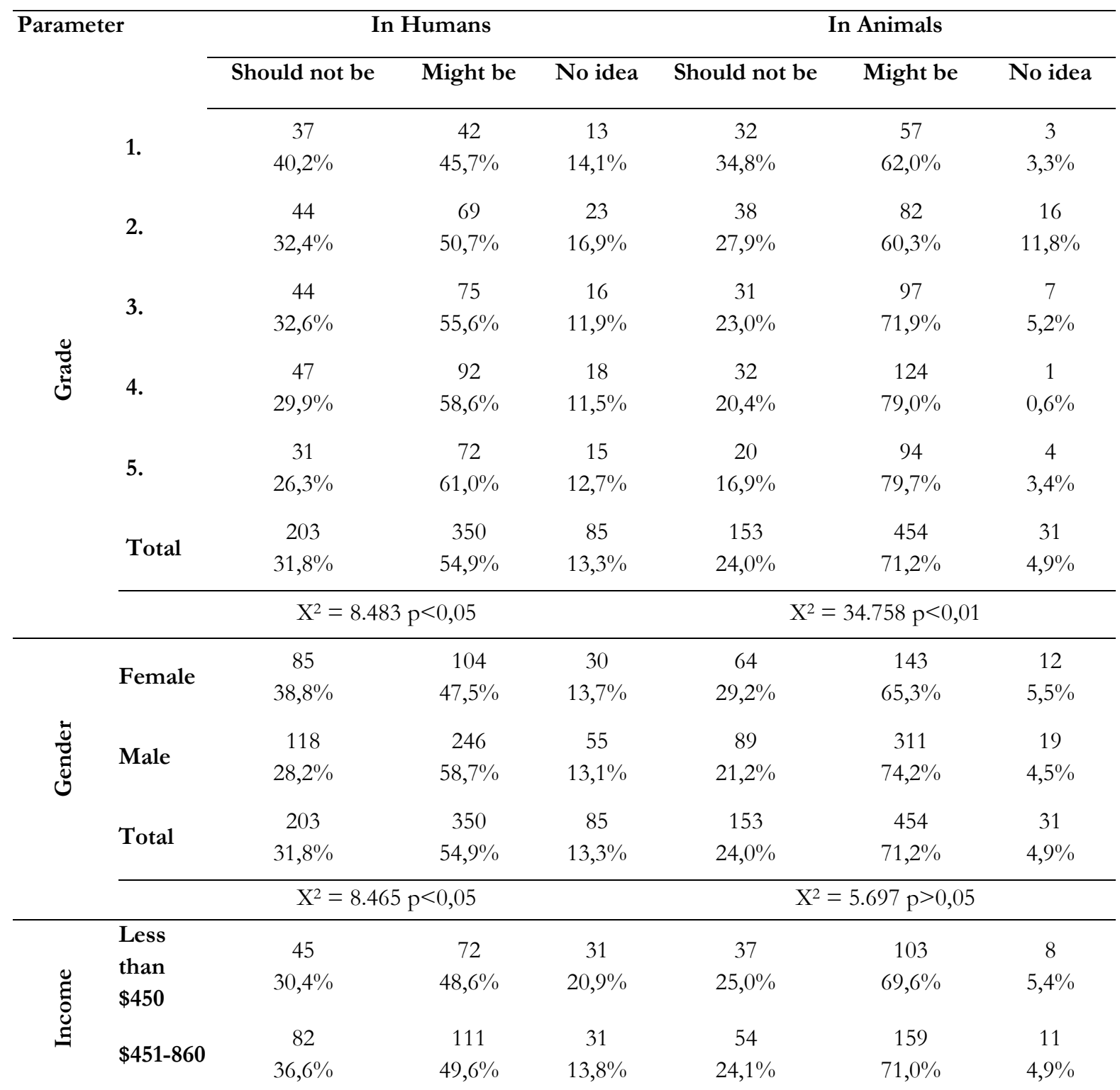




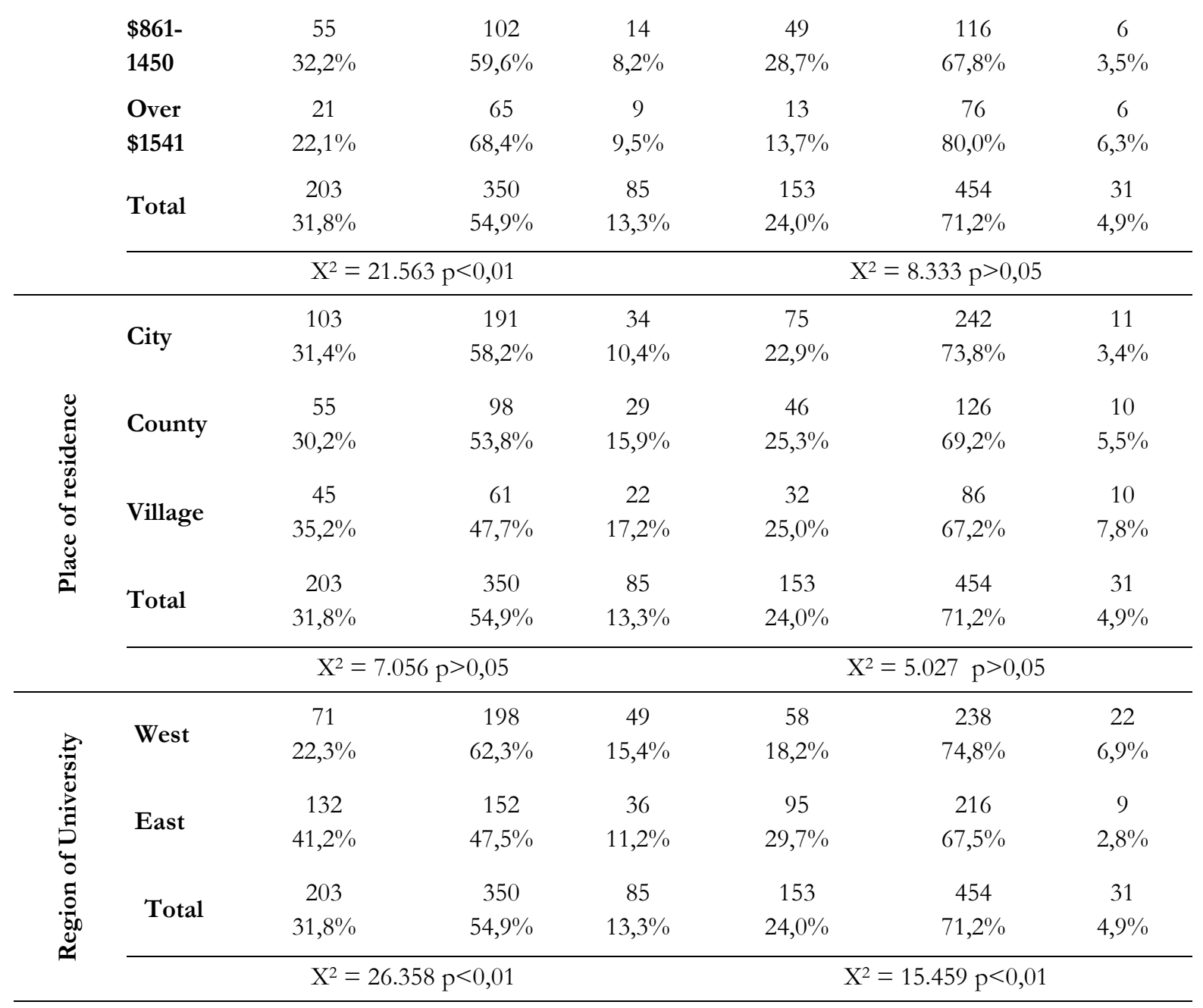

When Table 2 is examined, it is observed that the students who study at the first grade are against euthanasia in animals and in humans at higher rates; and this ratio gradually decreases at the higher grades. When the euthanasia viewpoints of the students were examined on the basis of gender and the location of the university, it was

found that having an attitude against euthanasia was higher in female students than males, and in the students that are in the eastern part than those in western part; and the difference in the chisquare analysis was found to be statistically significant. On the other hand, no statistically significant difference was found between the student's perspectives on animal euthanasia and the places they lived, and their income statuses. However, when Table 2 is examined, it is seen

that students with low income and that live in the village are against euthanasia at higher rates than those with higher incomes and live in cities.

In the questionnaire survey, $60.5 \%$ stated that veterinarians and $31.7 \%$ stated that the owners of the animals should have more rights to comment on the application of euthanasia; while $7.8 \%$ expressed that they did not have an idea on this subject. The views of participants on the process of decision-making about applying euthanasia are presented in Table 3.

When Table 3 is examined, it is seen that $83.1 \%$ of the participants think that the veterinarians 
should consider the demands of the animal owners on euthanasia regarding their animals.
However, it has been determined that $55.5 \%$ of the students think that religious beliefs should not

Table 3. The views of students on the process of decision-making about applying euthanasia

\begin{tabular}{|c|c|c|c|}
\hline Question & Yes & No & No İdea \\
\hline $\begin{array}{l}\text { Veterinarians should consider the demands of the animal } \\
\text { owners on euthanasia regarding their animals that are close } \\
\text { to death and/or have a high level of suffering }\end{array}$ & $\begin{array}{c}530 \\
(83,1 \%)\end{array}$ & $\begin{array}{c}66 \\
(10,3 \%)\end{array}$ & $\begin{array}{c}42 \\
(6,6 \%)\end{array}$ \\
\hline $\begin{array}{l}\text { The veterinarian is entitled to apply euthanasia on the } \\
\text { diseased animal in any circumstances }\end{array}$ & $\begin{array}{c}314 \\
(49,2 \%)\end{array}$ & $\begin{array}{c}250 \\
(39,2 \%)\end{array}$ & $\begin{array}{c}74 \\
(11,6 \%)\end{array}$ \\
\hline $\begin{array}{l}\text { What do you think, is it necessary to apply to a board } \\
\text { (ethics) other than the veterinarian and patient owner for } \\
\text { the application of euthanasia? }\end{array}$ & $\begin{array}{c}217 \\
(34,0 \%)\end{array}$ & $\begin{array}{c}334 \\
(52,4 \%)\end{array}$ & $\begin{array}{c}87 \\
(13,6 \%)\end{array}$ \\
\hline $\begin{array}{l}\text { Religious beliefs can be considered as an important } \\
\text { reference in the discussions regarding the euthanasia } \\
\text { practice on living creatures }\end{array}$ & $\begin{array}{c}166 \\
(26,0 \%)\end{array}$ & $\begin{array}{c}354 \\
(55,5 \%)\end{array}$ & $\begin{array}{c}118 \\
(18,5 \%)\end{array}$ \\
\hline
\end{tabular}

be considered as an important reference in the discussions regarding the euthanasia practice on living creatures.

In the study, $39.7 \%$ of the first grades, $42.4 \%$ of the second grades, $46.7 \%$ of the third grades, $53.5 \%$ of the fourth grades and $62.7 \%$ of the fifth grades responded by saying "yes" to the question of "The veterinarian is entitled to apply euthanasia on the diseased animal in any circumstances"; and in the analyses that were performed, the difference between grades and the views of the students was found to be statistically significant $\left(\mathrm{X}^{2}=23.461, \mathrm{p}=0,03\right)$. In addition, in the study, $34 \%$ of the students reported that it is necessary to apply to a board (ethics) other than the veterinarian and patient owner for the application of euthanasia. When the subject is assessed based on the grades, $43.7 \%$ of the first grade students, $38.2 \%$ of the second grade, $43.7 \%$ of the third grade, $29.9 \%$ of the fourth grade and $26.3 \%$ of the fifth grade responded as "yes", and in the analysis, the difference between the grades was found to be statistically significant $\left(\mathrm{X}^{2}=26.561, \mathrm{p}=0,01\right)$.

\section{Discussion}

The treatment and death of the patients, whose death are approaching, is one of the most difficult parts of the profession of being a veterinarian, as it is the same in medicine. In this respect, the necessity of euthanasia is also a matter of discussing the beliefs and emotions of the people as well as discussing the medical-ethical aspects. It may seem to be correct for others to make a decision for animals, which do not have the ability to make decisions about their own future, on being alive or dead, however, the responsibility of deciding and implementing it is undeniable (Singer, 1980).

The meanings that people attribute to death and their cultural and religious practices regarding death are different. In this study, 55.5\% of veterinary medicine faculty students reported that religious beliefs should not be considered as an important reference in discussions regarding the application of euthanasia on living creatures. Close to the findings of this study, Boz et al. (2003) found that $66.67 \%$ of medical faculty students thought that religious beliefs should not be considered in the practice of euthanasia. On the contrary; in the studies carried out by Çetinkaya and Karabulut (2016) and Demir et al. (2016) with the students of nursing department, it was determined that, respectively $74.9 \%$ and $74.7 \%$ of them were against euthanasia because of their religious beliefs. According to this information, it can be concluded that the 
perspectives gained during the education for the nursing departments and for the candidates of physicians are different.

It was determined that $70.5 \%$ of the participants reached the information about euthanasia during their education-training period at the faculty of veterinary medicine, Çetinkaya and Karabulut (2016) reported in their study that $68.7 \%$ of the students gained this information during their education in school, which is close to the findings of this study. In the study, it was determined that the students were against euthanasia at higher ratios in the first years of their education, however, this ratio decreased in the following years. This can be explained by the fact that students perceive professional difficulties more and have a broader view of the events due to having the applications of diagnosis and treatment and also important operations within the veterinary medicine education-training program at the higher grades in a more intense program.

In addition, it was found that the students, who study in the higher grades, have the opinion that the veterinarian always has the right to apply euthanasia when necessary at a higher rate, while the proportion of those who thought that another board (ethics) other than the veterinarian and the patient owner should be applied to was found to decrease. In the context of this data, it can be said that the higher grade students better understood the rights and responsibilities of the profession of being a veterinarian, as a result of the vocational training that they receive. Degeling et al. (2017) reported that Australasian veterinary students placed more importance on competency in AWE issues associated with clinical practice (such as neutering and euthanasia) than on professional behaviors (such as over-servicing and animal breeding).

In the interviews conducted, it was determined that female students were against euthanasia in higher rates than male students, and the difference between them was statistically significant. This can be explained by the fact that women empathize more than men. Yet, Serpell (2005) reported in their study that female students studying at faculty of veterinary medicine have higher anxiety than male students in the cases of animals that there's the possibility of pain. In addition to this study Hartnack et al (2016) reported that gender and age were found to be associated with views on euthanasia. In the study, female veterinarians and veterinarians having worked for fewer years were more likely to disagree with euthanasia. But females, compared to male veterinarians, who worked mostly in small animal practice, were performing more euthanasia per month.

In this study, although there was not a statistically significant difference between the residing places and income statuses of the students and their perspectives on euthanasia in animals, it was found to be remarkable that students, who had lower income levels and that were living in the village, were against applying euthanasia at higher rates than those with higher income levels that reside in cities. This is considered to be related to the empathizing abilities of the students.

For making the decision of applying euthanasia, the veterinarian should first understand what the physical and psychological needs of the diseased animal are, and whether death is necessary. From this point of view, the veterinarian needs to make and apply the euthanasia decision by taking the animal's general situation and health into consideration. However, the opinion of the owner of the animal is also important in deciding to apply euthanasia on the animal. Yet, at the point of making the decision of applying euthanasia, whether the veterinarian is able to take care of the animal or not, as well as the patient owner's feelings and thoughts, is another important issue to be considered. In the study, according to $83 \%$ of the students, an important proportion of them, the veterinarian should consider the euthanasia demands of the animal owners for their animals; however, the final decision in the animal euthanasia should be the veterinarian's according to $60.5 \%$ of the participants, and it should be patient owner's 
according to $31.7 \%$. Unlike this study, Christiansen et al. (2016) reported that different preferences are likely to exist amongst both veterinarians and clients about veterinary involvement in clients' decision-making, and such preferences may vary according to the situation. It is suggested, that one way to handle this challenge is to include respect for client preference on veterinary involvement under. In addition Kogure et al. (1990) reported that 44\% of veterinarians in Japan applied euthanasia on healthy animals with the requests of the owners of the animals, while this ratio was $74 \%$ in England. The difference between these studies is the fact that, in Turkey, euthanasia is prohibited on the healthy animals and euthanasia is seen as the last solution for the suffering animals.

In this study, $34 \%$ of the students also reported that a practice other than veterinarian and patient owner (ethics) should be applied for euthanasia. However, it can be said that the ethical committees are not responsible for the formation and legal structures of euthanasia when they are involved only in animal experiments.

As the result, while euthanasia is applied to animals only under certain conditions in Turkey; it was determined that the veterinarian candidates studying at the faculties of veterinary medicine generally view euthanasia as a medical practice. It was found that there are differences in the participants' approaches to euthanasia in terms of demographic structure, gender, culture, and lifestyle. Especially as the importance of pet keeping will increase in the upcoming years, it is obvious that the application of euthanasia in Turkey will become even more controversial. From this point of view, it can be said that the subject should be addressed together with all ethical values in faculties of veterinary medicine, professional organizations, professional chambers, and in related public institutions.

\section{References}

Anonim, 2011. Hayvan Haklar1: Hayvanların Korunması ve Refahı, İn: T.C. Avrupa Birliği Bakanliğ1, Ankara.

Ay MA., 2013. Hemşirelerin ölüm, ölümcül hasta ve ötenaziye ilişkin tutumları. HÜ Sağlık Bilimleri Enstitüsü Yüksek Lisans Tezi, Ankara.

Aypar Ü., 1997. Ötenazi. Hacettepe T1p Dergisi 28(1), 43-47.

Boz B., Kurtuluş A., Acar K., 2003. Pamukkale Üniversitesi Tip Fakültesi öğrencilerinin ötenaziye bakışı. Uluslararası Katılımlı 3. Ulusal Tip Etiği Kongresi Kongre Kitab1, Bursa, 958963.

Can R., Kadığlu S., Kadığlu F., 2006. Öğretim elemanı veteriner hekimlerin insan yönelik ötenazi uygulamalarına bakışı. 1. Ulusal Veteriner Hekimliği Tarihi ve Mesleki Etik Sempozyumu Bildirileri, Konya, 299-312.

Christiansen SB., Kristensen AT., Lassen J., Sandøe P., 2016. Veterinarians' role in clients' decision-making regarding seriously ill companion animal patients. Acta Veterinaria Scandinavica 58(30), 1-14.

Çetinkaya F., Karabulut N., 2016. Hemşirelik yüksekokulu öğrencilerinin ötenazi hakkında görüşleri. Journal of Hacettepe University Faculty of Nursing 3(2), 28-39.

Degeling C., Fawcett A., Collins T., Hazel S., Johnson J., Lloyd J., Phillips C., Stafford K., Tzioumis V., McGreevy P., 2017. Students' opinions on welfare and ethics issues for companion animals in Australian and New Zealand veterinary schools. Australian Veterinary Journal 95(6), 189-193.

Demir G., Biçer S., Ünsal A., 2016. Hemşirelik öğrencilerinin ötanaziye ilişkin düşünceleri. Gümüşhane University Journal of Health Sciences 5(1), 1-11. 
Düzgüneş O., Kesici T., Gürbüz F., 1983. İstatistik metotlar1. Ankara Üniversitesi Ziraat Fakültesi Yayın No: 861.

Hartnack S., Springer S., Pittavino M., Grimm H., 2016. Attitudes of Austrian veterinarians towards euthanasia in small animal practice: impacts of age and gender on views on euthanasia. BMC Veterinary Research 12(26), 114.

Kogure N., Yamazaki K., 1990. Attitudes to animal euthanasia in Japan: A brief review of cultural influences. Anthrozoös 3(3), 151-154.

Mandıracioğlu A., Özsoy SA., 2003. Ege Üniversitesi Tip fakültesi ve hemşirelik yüksekokulu son sınıf öğrencilerinin ötenazi konusuna yaklaşımları. Kriz Dergisi 3, 270-273.

Morris D., 1990. Çıplak Maymun (Çev: Nuran Yavuz), In: İnk1lap Press, İstanbul, p 256.

Morris D., 1991. Hayvan-İnsan Sözleşmesi (Çev: Mehmet Harmanc1). In: İnk1lap Press, İstanbul, p 151.

Nehir S., Karadeniz G., Altıparmak S., Tok N., 2006. Üniversite öğrencilerinin ötenaziye ilişkin düşünceleri: bir yüksekokul örneği. Fırat Sağllk Hizmetleri Dergisi 1(2), 26-36.

Özen Çınar İ., Kartal A., Önal A., 2012. Yoğun bakım ünitelerinde çalışan hemşirelerin ötanazi hakkındaki düşünceleri. Journal of Medical Ethics 20(3), 146-52.

Serpell JA., 2005. Factors influencing veterinary students' career choices and attitudes to animals. Journal of Veterinary Medical Education 32(4), 491-496.

Singer P., 1980. Animals and the value of life. Tom Regan (Ed.), Masters of Life and Death. Random Hause. New York.

Soysal Z., 1999. Adli Tip. In: İ.Ü Cerrahpaşa Tip Fakültesi Press, p: 105-106.

Tepehan S., Özkara E., Yavuz MF., 2011. Yoğun bakım ve diğer birimlerde görev yapan hemşirelerin ötanaziye yaklaşımı. Adli Tıp Dergisi 25(2), 115-124.

Yaşar A., 1997. Veteriner Hekimliğinde Ötanazi (Euthanasia). Vet Bil Derg, 13(2), 1-16. 